\title{
PELUANG REVITALISASI NILAI NILAI PANCASILA DALAM KEHIDUPAN BERBANGSA DAN BERNEGARA
}

\author{
Dr. Bambang Suteng Sulasmono, M.Si \\ sulasmonobambang@yahoo.com
}

\begin{abstract}
ABSTRAK
Sejak kelahirannya dasar negara Pancasila selalu berhadap-hadapan dengan paham kenegaraan pesaing, baik yang berasal dari luar maupun terlebih lebih yang berasal dari dalam negeri. Di tengah tahapan pengembangan budaya demokrasi sekarangpun Pancasila masih terus harus bersaing dengan paham kenegaraan yang bersumber dari kelompok keagamaan radikal. Oleh karena itu pengembangan demokrasi yang berlaku harus dibarengi dengan upaya revitalisasi nilai nilai Pancasila sebagai dasar negara, ideologi dan pandangan hidup bangsa Indonesia. Ada dua pendekatan yang perluditempuh dalam upaya itu yaitu pendekatan struktural dan pendekatan kultural. Pendekatan kultural hendaknya dilakukan untuk menyemai benih, menumbuhsuburkan dan menjaga kelestarian nilai nilai Pancasila melalui proses pendidikan dan pembiasaan (habituasi) bagi segenap komponen bangsa. Pendidikan dan pembiasaan nilai-nilai Pancasila dalam kehidupan berbangsa dan bernegara wajib ditopang oleh penciptaan struktur kehidupan berbangsa dan bernegara yang sejalan dengan nilai-nilai Pancasila

Kata kunci: revitalisasi nilai, Pancasila, pendekatan struktural, pendekatan kultural
\end{abstract}

\section{PENDAHULUAN}

Selepas dari pemerintahan otoriter Orde Baru, bangsa Indonesia terus berproses dalam perjuangan demokratisasi kehidupan bernegara. Sebagaimana sudah sering dikemukakan banyak pihak, demokratisasi itu sesungguhnya merupakan proses yang berkesinambungan. Ada empat tahapan proses demokratisasi yang harus dilewati, sebagai berikut ini.

(1) tahap pembusukan rejim otoriter, di mana rejim yang lama mengalami kebangkrutan akibat berbagai praktik penyimpangan (korupsi kolusi, nepotisme, dan sebagainya) di tubuh rejim itu sendiri.

(2) tahap transisi yang merupakan periode penuh ketidak-pastian politik yang tinggi dengan resiko pembelokkan arah kembali ke pola rejim lama, walau disertai dengan berkembangnya benih-benih rejim baru

(3) tahap konsolidasi yaitu tahap di mana mulai terbentuk konsensus dasar di antara elit politik mengenai aturan main dan lembaga-lembaga demokratis yang hendak dijalankan di negara yang bersangkutan

(4) tahap kematangan tatanan politik demokratis yang ditandai oleh evolusi budaya politik demokratis

Kini bangsa kita telah menjalani tahapan transisi dan konsolidasi. Amandemen UUD 1945 yang telah berlangsung empat kali mencerminkan terjadinya 'konsensus dasar di antara elit politik mengenai aturan main dan lembaga-lembaga demokratis yang hendak dijalankan' di negara ini. Namun harus diakui pula bahwa tarik menarik antara kekuatan lama dengan kekuatan baru masih terus menggejala, sehingga mengingatkan kita bahwa bangsa ini memang belum mampu melewati masa transisi sepenuhnya. 
Seruan berbagai pihak tentang pentingnya bangsa ini tetap berpegang teguh kepada "common platform" yang sudah disepakati bersama yaitu Pancasila dan Undang Undang Dasar 1945 mengisyaratkan bahwa masa transisi ini juga diwarnai oleh berkembangnya tawaran untuk menggunakan platform hidup bernegara lain di luar Pancasila. Tampak bahwa Pancasila kini tidak saja harus berhadap-hadapan dengan ideologi lain yang berasal dari luar yaitu kapitalisme, individualisme maupun sosialisme, namun juga harus bersaing dengan ideologi lain yang berasal dari khasanah kehidupan bangsa Indonesia itu sendiri

Beberapa pertanyaan yang sering muncul sehubungan dengan upaya revitalisasi nilai-nilai Pancasila adalah sebagai berikut: a) Apakah nilai-nilai Pancasila sebagai falsafah bangsa masih hidup dan menghidupi kalbu setiap manusia Indonesia?; b) Sudahkah nilai-nilai Pancasila berada pada lajur yang tepat dalam kehidupan berbangsa dan bernegara kita?; c) Sejauh manakah nilai-nilai Pancasila terimplementasikan secara yang integratif dalam kehidupan berbangsa dan bernegara?; Kemudian, d) Bagaimanakah metode, formulasi dan sistematisasi pengimplementasian nilai-nilai Pancasila dalam kehidupan berbangsa dan bernegara?; serta e) Bagaimanakah peluang dan tantangan ke depan yang harus kita hadapi bersama dalam kerangka melaksanakan revitalisasi nilainilai Pancasila dalam kehidupan berbangsa dan bernegara? (MPR RI: 2016: 1). Dari berbagai pertanyaan di atas penulis sengaja memilih untuk mencoba menjawab pertanyaan terakhir yaitu tentang peluang bagi revitalisasi nilai-nilai Pancasila dalam kehidupan berbangsa dan bernegara di Negara Kesatuan Republik Indonesia.

Pertimbangan dipilihnya pertanyaan itu adalah bahwa diduga kuat topik semaca, ini ini belum terlalu mendapat perhatian dari berbagai pihak yang relevan. Lebih dari itu, pilihan topik itu juga dilandaskan pada satu pertimbangan mendasar yaitu bahwa peluang bagi revitalisasi nilai nilai Pancasila sesungguhnya sangat bergantung pada daya tahan nilai-nilai Pancasila dalam persaingan antar paham kenegaraan yang terus berlangsung hingga saat ini. Sejalan dengan pandangan Alfian (1980) yang menyatakan bahwa ada tiga dimensi pokok sebuah ideologi yaitu (a) dimensi idealitas, (b) dimensi realitas dan (c) dimensi fleksibilitas, maka besar kecilnya atau bahkan ada atau tidaknya peluang bagi revitalisasi nilai-nilai Pancasila sesungguhnya sangat tergantung pada keterpenuhan ketiga dimensi pokok ideologi tersebut dalam diri Pancasila itu sendiri dari masa ke masa. Oleh karena itu tulisan ini hendak dimulai dengan pemaparan tentang persaingan Pancasila dengan paham kenegaraan lain, sebelum kemudian dipaparkan peluang bagi revitalisasi nilai-nilai Pancasila itu sendiri.

Sejak awal perumusannya Pancasila sesungguhnya sudah harus bersaing dengan paham-paham kenegaraan lain. Dari sejarah perumusan Pancasila tampak bahwa sebagai paham kebangsaan Pancasila harus bersaing dengan paham kenegaraan lain yaitu Islam dan komunisme. Dalam perjalanan hidupnya - paling tidak sampai akhir tahun 1980-an boleh dikatakan Pancasila juga selalu berada dalam posisi persaingan dengan dua paham kenegaraan, yaitu Islam dan komunisme, dan selama masa Orde Baru juga dengan paham integralistik. Jika secara internal Pancasila harus bersaing dengan ketiga paham di atas maka secara eksternal Pancasila juga sering dipertentangkan dengan liberalisme yang berakar pada individualisme, dan sosialisme. 
Sebelum Indonesia merdeka, aspirasi politik bangsa Indonesia tentang dasar negara, utamanya perihal hubungan antara agama dan negara dalam negara yang hendak dibangun terbelah menjadi dua. Pada satu sisi ada yang menginginkan penyatuan negara dan agama (Islam) ke dalam Negara Islam Indonesia sebagaimana diaspirasikan antara lain oleh Partai Syarikat Islam, dan pada sisi lain ada yang menginginkan pemisahan negara dengan agama sebagaimana diaspirasikan oleh kelompok nasionalis, seperti diaspirasikan oleh Partai Nasional Indonesia dan dalam batas tertentu juga oleh Partai Komunis Indonesia (Noer, 1983).

Oleh karena itu dalam proses perumusan sila pertama dasar negara Indonesia Pancasila, rumusan sila yang mengatur hubungan negara dengan agama, sempat mengalami dua kali perubahan, dari "Ketuhanan Yang Berkebudayaan" (versi Soekarno 1 Juni 1945), menjadi "Ketuhanan dengan kewajiban menjalankan syariat Islam bagi pemeluk-pemeluknya (versi Piagam Jakarta, 16 Juni 1945) dan kembali ke "Ketuhanan Yang Maha Esa” (versi PPKI tanggal 18 Agustus 1945). Hal itu mencerminkan terjadinya pergumulan ideologis di antara para pendiri bangsa tentang bagaimana sebaiknya hubungan negara dengan agama di Indonesia jika merdeka kelak. Keputusan akhir tentang sila pertama Pancasila itupun kuat nuansa fait acomplinya karena tokohtokoh Islam terpaksa mengalah untuk menerima rumusan itu demi keutuhan negara Indonesia yang terancam pecah akibat munculnya aspirasi untuk memisahkan diri dari utusan bangsa Indonesia di bagian timur. Menjadi dapat dipahami jika kemudian geraskan untuk mengembalikan rumusan sila pertama Pancasila ke versi Piagam Jakarta selalu muncul dari waktu ke waktu, sebagaimana ditunjukkan dalam sidang Konstituante 1957 - 1959, sidang-sidang Majelis Permusyawaratan Rakyat Sementara di awal Orde Baru (1966-1968), dan persidangan Majelis Permusyawaratan Rakyat selama proses amandemen UUD 1945 di awal masa reformasi tahun 1999 (Subekti, 2008)

Momen-momen tersebut menunjukkan bahwa walaupun kekuatan politik yang memperjuangkan penyatuan negara dan agama mengalami pasang surut kehidupan, namun aspirasi atau cita-cita itu terus bertahan dari masa ke masa, dari generasi ke generasi. Masyumi dan NU sebagai kekuatan politik Islam merupakan 2 (dua) dari 4 (empat) partai pemeroleh suara terbesar pada pemilu tahun 1955. Masyumi pulalah, lewat tokohnya M. Natsir, yang gigih memperjuangkan prinsip penyatuan negara dengan agama dalam siding-sidang konstituante, siding pembentuk Undang Undang Dasar sebagai pengganti UUD S 1950, tahun 1957 -1959. Hal semacam itu sangat dimungkinkan terjadi karena iklim politik yang dikembangkan pada saat itu memang bernuansa liberal yang amat menghargai kebebasan. Keadaan berubah dratis ketika pemerintahan Soekarno dengan Demokrasi Terpimpinnya menjadi sangat represif terhadap siapapun yang dipandang sebagai lawan politiknya, termasuk Masyumi yang kemudian dibubarkan karena dianggap terlibat dalam gerakan PRRI/Permesta. Rejim Orde Baru, yang menggantikan rejim Soekarno, juga menerapkan kebijakan yang tidak kondusif bagi kekuatan politik Islam di Indonesia. Kebijakan asas tunggal, yang mewajibkan semua partai politik berasaskan Pancasila, pelarangan penggunaan simbol-simbol keagamaan sebagai lambang partai, pengawasan ketat terhadap wacana kenegaraan di berbagai kelompok masyarakat, kebijakan represif terhadap gerakan-gerakan yang dipandang 
mengancam stabilitas negara, dan lain sejenisnya telah melahirkan reaksi yang beragam di kalangan Islam.

Dalam analisa Adnan (Budiman 1990) kekuatan Islam pada masa Orde Baru dapat dikategorikan menjadi tiga kelompok yaitu (a) kelompok Akomodatif, (b) kelompok Idealis Moderat, dan (c) kelompok Idealis Radikal. Kelompok akomodatif adalah kelompok yang berpandangan bahwa Islam tidak pernah memerintahkan pembentukan negara Islam, karena itu negara semacam itu tidak pernah ada dalam sejarah Islam. Oleh karena itu kaum muslim tidak perlu berjuang mewujudkan negara Islam. Sebab Islam mengubah masyarakat secara budaya, Islam berkembang bukan karena ideologinya melainkan karena budayanya. Jadi untuk mengubah masyarakat kaum muslim lebih tepat menggunakan pendekatan budaya ketimbang pendekatan ideologis, yang memerlukan kekuasaan. Mereka menerima Pancasila sebagai asas tunggal. Kelompok Idealis Modernis juga menerima Pancasila, namun mereka berpandangan bahwa selain agama, Islam adalah juga ideologi. Mereka berupaya memperluas kesadaran kaum Muslim agar memahami bahwa Islam bukanlah sekedar agama melainkan juga ideologi. Sedang kelompok Idealis Radikal berjuang dengan pendekatan yang lebih progresif. Mereka menentang negara dalam dakwah-dakwah yang menggugah emosi massa. Mereka menolak penetapan Pancasila sebagai satu-satunya asas, dan tidak percaya pada pernyataan-pernyataan penguasa yang menjamin bahwa Pancasila tidak akan menggusur peran agama. Tindakan kaum idealis radikal akhirnya terwujud dalam berbagai kekerasan politik, seperti pembajakan pesawat Woyla, kasus GPK Warsidi Lampung, kasus Tanjung Priok dll.

Berakhirnya pemerintahan Suharto di tahun 1998 menjadi titik tolak bangkit kembalinya kekuatan politik Islam. Menjelang pemilu 1999, bermunculan partai politik dengan identitas Islam. Marijan (2010) misalnya, mencatat tak kurang dari 28 partai bercorak Islam, namun hanya 21 partai Islam yang dapat ikut pemilu 1999 dan kemudian menjadi 8 partai pada pemilu tahun 2004. Sama seperti pada masa lalu, partai partai politik berlabel Islam tersebut juga tidaklah tunggal. Fealy 2001 (dalam Marijan, 2010) misalnya membedakan antara partai Islam yang masuk kategori "formalist Islamic parties" dan yang masuk kategori "pluralist Islamic parties". PPP, PBB dan PKS adalah partai partai yang masuk dalam kategori formalis, sedang PAN dan PKB masuk ke kategori pluralis. Jika PPP dan kawan-kawannya berusaha memperjuangkan nilai-nilai Islam ke dalam perundang-undangan dan kebijakan-kebijakan negara, maka PKB dan PAN lebih berusaha memperjuangkan nilai-nilai Islam di dalam kontkes negara-bangsa Indonesia yang plural. Kelompok formalis itu sendiri sebenarnya masih bisa dipilah menjadi kelompok "moderate formalist Islamic parties", semacam PPP dan "radical formalist Islamic parties" semacam PKS dan PBB.

Kevin Evans (sebagaimana telah dimodifikasi oleh Pratikno, 2007) memetakan partai-partai politik dewasa ini sebagai berikut: 
Gambar 1

Pemetaan Parpol Berdasarkan Basis Ideologi

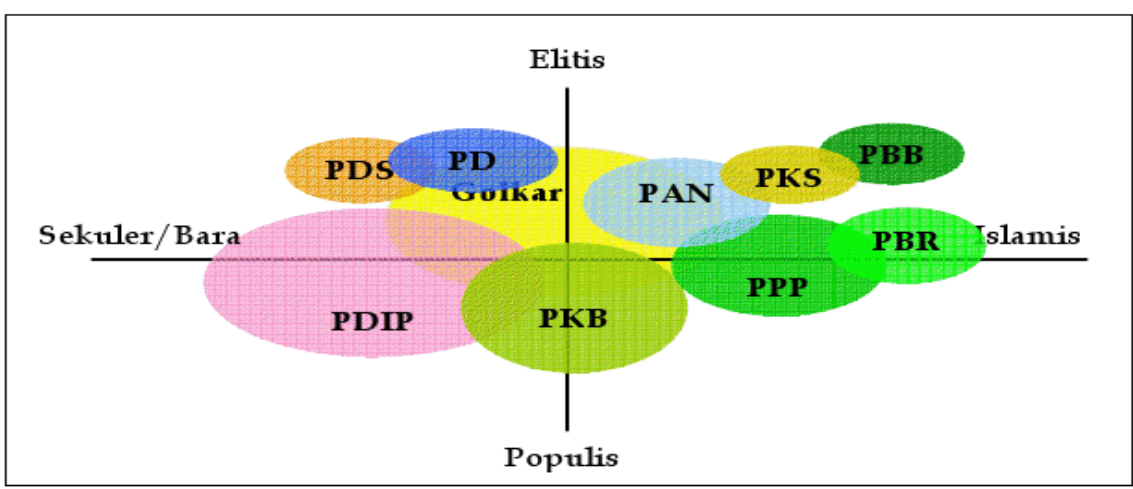

Tampak bahwa pemetaan Evan di atas, khususnya untuk partai-partai Islam cukup sejalan dengan kategorisasi yang dikemukakan oleh Fealy di atas.

Disamping partai politik Islam, lahir pula kelompok-kelompok kepentingan dan kelompok penekan berbasis agama. Kelompok kepentingan yang telah lama adaseperti Muhammadiyah dan NU terlibat dalam pembentukan partai baru yaitu PAN dan PKB. Di samping itu muncul kelompok-kelompok baru seperti DI/NII, Jama'ah Islamiyah (JI), Majelis Mujahidin Indonesia (MMI), Fornt Pembela Islam (FPI), Forum Komunikasi Ahlu Sunnah wal Jamah (FKAWJ), dan Hizbut Tahrir (HT). Marijan (2010) menggambarkan sikap politik kelompok-kelompok Islam radikal tersebut sebagai berikut:

Sikap Politik Kelompok Islam Radikal

\begin{tabular}{|c|c|c|c|c|}
\hline Kelompok & $\begin{array}{c}\text { Syariah } \\
\text { Komprehensif }\end{array}$ & Negara Islam & Khalifah & Demokrasi \\
\hline DI/NII & Ya & Ya & Tidak & Tidak \\
\hline Jamaah Islamiyah & Ya & Ya & Ya & Tidak \\
\hline MMI & Ya & Ya & Ya & Tidak \\
\hline FPI & Ya & Tidak & Tidak & Ya \\
\hline FKAWJ/LJ & Ya & Tidak & Tidak & Tidak \\
\hline Hizbut Tahrir & Ya & Ya & Ya & Tidak \\
\hline
\end{tabular}

Sumber: Kacung Marijan (2010)

Keenam organisasi di atas memang kecil massa pendukungnya, namun mereka sangat aktif dalam memperjuangkan kepentingan-kepentingan mereka. FPI aktif menyuarakan penegakkan hukum Islam, terlibat dalam pengegerebekan tempat-tempat maksiat, di DKI, dan tempat-tempat lainnya. FKAWJ terlibat langsung dalam konflik antar agama di daerah-daerah konflik semacam Maluku dan Poso. Sedang JI merupakan organisasi yang sejumlah anggotanya terlibat aksi terorisme bukan saja di Indonesia namun juga di Asia Tenggara. Uraian di atas menunjukkan bahwa dari masa ke masa Pancasila selalu diperhadapkan kepada berbagai paham kenegaraan pesaing. Oleh karena 
itu revitalisasi nilai-nilai Pancasila bukanlah hal yang mustahil, walaupun juga bukan merupakan hal yang mudah untuk dilakukan. Dari ketiga dimensi ideologi Pancasila, aspek idelaitas Pancasila tentu tak diragukan lagi.

\section{Peluang dan Upaya Revitalisasi Nilai Nilai Pancasila}

Pancasila memiliki bangunan nilai-nilai yang dapat menjawab lima persoalan dasar dalam hidup bernegara yaitu: (a) bagaimana hubungan antara negara dan agama di negara Indonesia, (b) bagaimana hubungan antar bangsa Indonesia dengan bangsa lain di dunia, (c) apakah hakikat negara yang hendak didirikan itu, (d) siapakah pemilik kedaulatan dalam negara dan bagaimana melaksanakannya, serta (e) apakah tujuan negara yang hendak didirikan itu. Dari dimensi fleksibilitas, fakta bahwa Pancasila masih tetap dipertahankan oleh bangsa Indonesia hingga saat ini secara tidak membuktikan daya lentur ideologi Pancasila. Oleh karena itu tantangan terbesar dalam upaya revitalisasi nilai-nilai Pancasila sesungguhnya adalah bagaimana memperkuat dimensi realitas ideologi Pancasila. Wujud nyata dari implementasi nilai-nilai Pancasila harus benar-benar mampu ditampakkan dalam kehidupan berbangsa dan bernegara dari waktu ke waktu.

Usaha untuk mewujudkan nilai nilai Pancasila dalam kehidupan berbangsa dan bernegara harus dilaksanakan melalui dua pendekatan komplementer yaitu pendekatan kultural dan (2) pendekatan struktural. Pendekatan kultural hendaknya dilakukan untuk menyemai benih, menumbuhsuburkan dan menjaga kelestarian nilai nilai Pancasila melalui proses pendidikan dan pembiasaan (habituasi) bagi segenap komponen bangsa, terlebih-lebih generasi muda agar semakin kuat komitmen kebangsaannya, semakin kuat penghayatan mereka sebagai sebuah "imagined community" yang dipersatukan oleh keragaman yang ada. Upaya kultural itu juga sekaligus untuk memerangi beberapa kendala revitalisasi nilai-nilai Pancasila yang kita hadapi yaitu : (a) kuatnya in-group feeling di kalangan suku-suku bangsa, (b) etnosentrime, dan (c) eksklusivisme. Perasaan in-group yang kuat di kalangan suku-suku bangsa pada satu sisi memang bernilai positif namun pada sisi lain dapat menimbulkan sikap pengutamaan segala sesuatu yang menyangkut sukunya secara berlebihan sehingga menghambat perwujudan kesetiaan terhadap negara secara nasional. Etnosentrime adalah paham yang memandang kebudayaan suku bangsanya sebagai yang terbaik sementara kebudayaan suku bangsa lain dianggap rendah. Sikap semacam ini jelas tidak mendukung upaya integrasi nasional yang mensyaratkan adanya kesediaan dari setiap pihak untuk saling menghargai dan menghormati kekhasan atau ciri khas pihak lain. Etnosentrisme juga dapat mendorong lahirnya eksklusivisme, atau paham menutup diri. Eksklusivisme akan melahirkan sikap eksklusif atau menutup diri dari lingkungan sekitar dan hanya mengembangkan kehidupan di dalam kelompoknya sendiri.

Pendidikan dan pembiasaan nilai-nilai Pancasila dalam kehidupan berbangsa dan bernegara wajib ditopang oleh penciptaan struktur kehidupan berbangsa dan bernegara yang sejalan dengan nilai-nilai Pancasila. Dewasa ini, sesudah lebih dari 15 tahun kita berada pada masa transisi, tampak bahwa Indonesia telah berhasil melewati dua dari tiga tahapan mewujudkan demokrasi, yaitu "façade democracy", dan "electoral democracy" guna menuju "full democracy" (Haynes 2001, dalam Erb dan Sulistyanto, 2010). Karakteristik dari rejim façade democracy adalah bahwa walau dalam negara itu 
dijalankan pemilu secara regular, namun pemilu itu sendiri sangat dikendalikan oleh pihak penguasa, dan dalam rejim itu militer memainkan peran penting dalam mengendalikan "law and order", di mana hak-hak asasi manusia tidak dipandang penting dalam penyelenggaraan pemerintahan negara. Gambaran seperti itu mengingatkan kita pada praktik kehidupan bernegara bangsa Indonesia semasa Orde Baru. Demokrasi yang diberi label Pancasila pada waktu itu hanya demokrasi seolah-olah (Suseno, 1995), karena walau pemilu dilaksanakan secara rutin 5 tahun sekali namun kebanyakan pemilu itu berlangsung dengan penuh kecurangan, dikontrol ketat oleh penguasa, di mana militer menjalankan fungsi "screening" bagi setiap orang yang hendak dicalonkan menjadi pejabat publik (Lidle, 1992, Weathrebee, 2001; Suryadinata, 2002). Peran dominan militer dalam kehidupan politik semasa Orde baru juga sudah banyak dicatat oleh para ahli (Crouch, 1978; Sundhausen, 1986; dan Britton, 1996), sedang rekam jejak pelanggaran atau paling tidak pengabaian hak asasi manusia oleh rejim Orde baru juga dapat kita temukan dalam banyak pustaka.

Karakteristik rejim electoral democracy adalah terdapatnya aturan-aturan dan regulasi tentang penyelenggaraan pemilu demokratis yang benar-benar terlaksana dalam praktik kehidupan bernegara. Di samping itu dalam rejim ini terdapat pula perhatian terhadap proses penegakkan hukum. Hal yang membedakan antara electoral democracy dengan full democracy adalah jika dalam electoral democracy baru sebatas prosedurprosedur pemilu yang benar benar menjamin hak-hak individu dan partisipasi mereka dalam proses pemilu, maka dalam full democracy seluruh upaya penyelenggaraan negara benar-benar dipusatkan untuk menjamin hak-hak individu dan partisipasi mereka dalam proses politik dan urusan public, di mana penyelenggara negara benar-benar menerapkan prinsip penyelenggaraan pemerintahan negara yang partisipatif, transparan dan akuntabel.

Seusai pemerintahan rejim Orde baru bangsa Indonesia telah berupaya untuk mewujudkan komitmen menjalankan sistem pemerintahan demokratis. Hal itu antara lain diwujudkan melalui pelaksanaan pemilu kompetitif multipartai; jaminan dan perlindungan atas kebebasan pers, kebebasan berserikat dan berkumpul; penyingkiran militer dari arena politik praktis, dan pelaksanaan desentralisasi secara luas. Lebih lanjut, pada tahun 2004 mulai dilaksanakan pemilihan presiden dan wakil presiden secara langsung, serta tahun 2005 mulai dilaksanakan pemilihan kepala daerah secara langsung. Proses dan hasil pemilu tahun 1999 dan 2004 mendapat apresiasi positif dari banyak pihak. Itu semua menunjukkan bahwa Indonesia telah berhasil mencapai tahapan sebagai rejim electoral democracy.

Akankah perjalanan hidup bangsa Indonesia terus melaju ke tahapan full democracy? Haynes 2001 (Erb dan Sulistyanto, 2010) mencatat bahwa paling tidak ada delapan hambatan yang dapat menghadang proses menuju full democracy yaitu: a) dominasi eksekutif yang eksesif, b) sistem sosial-politik patrimonial baru, c) korupsi tingkat negara yang serius, d) partai-partai politik yang lemah dan tidak stabil, e) pelemahan atau kooptasi kekuatan civil society, f) pembelahan etnis/keagamaan yang serius, g) kemiskinan yang menyebar secara luas, dan h) iklim internasional yang tidak mendukung. Dari kedelapan penghambat tersebut bangsa Indonesia mengahadapi persoalan akut di bidang pemberantasan korupsi. Hasil survey Transparency International 
(2011) mendudukkan Indonesia sebagai negara terkorup keenam di dunia. Untuk tahun ini, berdasarkan hasil survey nilai Indeks Persepsi Korupsi Indonesia adalah 2,2. Nilai ini sejajar dengan negara Azerbaijan, Kamerun, Irak, Etiopia, Liberia dan Uzbekistan. Peringkat Indonesia tergolong lebih baik dibandingkan Paraguay, Somalia, Sudan, Angola, Nigeria, Kongo, Kenya, Haiti, dan Myanmar. Sementara, untuk negara yang dianggap paling bersih dari korupsi adalah Islandia dengan nilai indeks 9,7. Partai-partai politik belum mampu berfungsi sebagaimana mestinya dan bahkan menjadi wahana pengembangan sistem sosial politik patrimonial baru. Memang tidak terjadi kooptasi terhadap organisasi-organisasi kemasyarakatan (civil society), namun sebaliknya beberapa organisasi civil society yang tumbuh dan berkembang selama masa transisi ini justru sering merusak tatanan demokrasi yang hendak dibangun melalui berbagai tindakan anarkis. Lebih dari itu, kini juga telah tumbuh dan berkembang beberapa organisasi civil society yang sejatinya memang anti sistem demokrasi (Marijan: 2010). Kebebasan yang berkembang sejalan dengan proses demokratisasi kehidupan berbangsa dan bernegara selama ini juga membawa dampak iringan intensnya konflik antar suku/kelompok maupun penganut agama. Kemiskinan belum juga mampu dikurangi secara signifikan oleh pemerintah. Dengan demikian masih diperlukan kerja keras seluruh elemen bangsa ini jika memang berkehendak untuk mewujudkan kehidupan demokrasi yang penuh. Itu berarti diperlukan adanya upaya pendalaman demokrasi atau deepening democracy. Berbagai kajian terhadap transisi demokrasi di Asia, Amerika Latin dan Eropa Timur menunjukkan bahwa kelangsungan atau daya tahan demokrasi amat dipengaruhi oleh berlangsung atau tidaknya proses peningkatan mutu demokrasi dari konsepsi minimalis, demokrasi prosedural, menuju bentuk yang lebih substantif dari politik demokratis, demokrasi substansial (Anderson ed, 1999; Przeworski et al, 1996; Linz \& Stephan, 1996). Gejala demikian umumnya disebut sebagai proses pendalaman demokrasi (deepening democracy).

Wong (2003:235) memahami pendalaman demokrasi sebagai proses sosial, ekonomi dan politik yang berlangsung sepanjang waktu. Pendalaman demokrasi tidak berakhir dalam dan pada dirinya sendiri. Di sini arah perubahan amat ditekankan. Penekanan pendalaman sebagai sebuah proses ini memberi pengertian mengenai apa yang menandai adanya pendalaman demokrasi. Roberts (1998:3), menyatakan bahwa pendalaman demokrasi memiliki sekaligus konotasi prosedural dan substantif dalam berdemokrasi. Karena itu pendalaman demokrasi bisa dipahami sebagai proses di mana politik progresif atau politik baru menjadi bagian penting dari agenda politik utama yang dijalankan pemerintah dan masyarakat.

Menurut Fung and Wright (Pratikno 2007) deepening democracy perlu berlangsung dari dua sisi: sisi negara dan sisi masyarakat. Dari sisi negara, deepening democracy, adalah pengembangan dua hal, pertama, pelembagaan mekanisme (institutional design) penciptaan kepercayaan semua aktor politik di daerah yakni masyarakat sipil, masyarakat politik (partai politik) dan tentu saja negara atau state apparatuses (birokrasi, alat keamanan negara). Kedua, pengembangan penguatan kapasitas administratif-teknokratik yang mengiringi pelembagaan yang telah ditetapkan. Dari sisi masyarakat, deepening democracy, merujuk pada pelembagaan keterlibatan masyarakat terhadap aktivitas politik formal di tingkat local state. 
Dalam tataran riil, setidaknya ada tiga dimensi yang menandai berlangsungnya pendalaman demokrasi (Wong, 2003). Pertama, dimensi sosio-legal atau institusionalisasi hak-hak politik, yang merujuk pada gagasan hak asasi manusia, martabat manusia dan kesetaraan manusia. Ini meliputi antara lain perluasan kesetaraan hak suara, perluasan peluang yang sah secara hukum (ruang legal) bagi masyarakat untuk berserikat dan berkumpul, serta perluasan hak masyarakat untuk berpartisipasi dalam berbagai tingkatan proses politik. Pendalaman demokrasi mengupayakan dan mengkodifikasikan secara legal penghargaan hak asasi manusia lintas kategori sosial, tanpa pandang bulu terhadap kelas sosial, agama, etnisitas, gender dan berbagai kategori sosial lainnya. Kebijakan politik dirancang sedemikian rupa untuk mencegah dan mengatasi terjadinya diskriminasi terhadap individu dan kelompok-kelompok sosial, mempromosikan penghargaan terhadap hak asasi manusia, serta menanamkan sikap yang menghargai keragaman atau kebhinekaan.

Kedua, dimensi ekonomi, yang merujuk pada distribusi dan alokasi sumbersumber yang terdapat dalam masyarakat. Masyarakat umumnya mengharapkan bahwa dimulainya pemerintahan demokrasi akan menghantar mereka pada terwujudnya keadilan sosial ekonomi yang lebih besar (Przeworski, 1999:10). Karena itu, adanya redistribusi ekonomi dan inovasi kebijakan sosial merupakan hal amat penting yang menandai berlangsungnya pendalaman demokrasi (Kapstein \& Mandelbaum Ed, 1997; Chalmers et al., 1997; Weyland, 1996 dalam Wong 2003). Reformasi kebijakan sosial, yang memiliki dimensi ekonomi lebih umum, juga merupakan tanda berlangsungnya pendalaman demokrasi. Reformasi demikian ditandai oleh berlangsungnya perluasan tanggung jawab pemerintah (katimbang mengandalkan mekanisme pasar) dalam mendistribusikan keuntungan-keuntungan ekonomi dan mengalokasikan sumber-sumber yang langka / terbatas. Termasuk dalam hal ini berlangsungnya perubahan kebijakan kesejahteraan sosial dan pelestarian lingkungan.

Ketiga, dimensi politik, yang merujuk pada partisipasi masyarakat dalam politik, khususnya dalam proses pembuatan kebijakan. Dalam hal ini, pendalaman demokrasi hakikatnya merupakan upaya mempertimbangkan kembali negara sebagai arena bagi berlangsungnya perundingan dalam pembuatan keputusan (deliberative decision making). Menurut Chalmers et al (1997, dalam Wong 2003), hal ini merupakan garansi bahwa hak partisipasi politik yang dijamin oleh hukum (de jure) benar-benar dapat diwujudkan dalam praktik partisipasi politik secara nyata (de facto). Jadi, singkatnya, dalam dimensi politik, pendalaman demokrasi berarti perubahan dalam proses politik dan pembuatan kebijakan. Dalam hal ini, tingkat pengaruh aktor di luar aparat pemerintah dalam menentukan pembaruan agenda kebijakan, serta sejauh mana pembuatan keputusan pemerintah telah diambil melalui konsensus katimbang pembebanan, itu semua mengindikasikan sejauh mana tingkat pendalaman demokrasi sekaligus kebermaknaan partisipasi dan representasi politik.

\section{Penutup}

Dari uraian singkat di atas dapatlah ditarik beberapa simpulan tentang peluang revitalisasi nilai-nilai Pancasila sebagai berikut: 
a) Revitalisasi nilai-nilai Pancasila bukanlah hal yang mustahil, walaupun juga bukan merupakan hal yang mudah untuk dilakukan, karena tantangan terbesar dalam upaya revitalisasi nilai-nilai Pancasila sesungguhnya adalah bagaimana memperkuat dimensi realitas ideologi Pancasila.

b) Usaha untuk mewujudkan nilai nilai Pancasila dalam kehidupan berbangsa dan bernegara harus dilaksanakan melalui dua pendekatan komplementer yaitu (1) pendekatan kultural dan (2) pendekatan struktural. Pendekatan kultural hendaknya dilakukan untuk menyemai benih, menumbuhsuburkan dan menjaga kelestarian nilai nilai Pancasila melalui proses pendidikan dan pembiasaan (habituasi) bagi segenap komponen bangsa,

c) Pendidikan dan pembiasaan nilai-nilai Pancasila dalam kehidupan berbangsa dan bernegara wajib ditopang oleh penciptaan struktur kehidupan berbangsa dan bernegara yang sejalan dengan nilai-nilai Pancasila, yaitu upaya pendalaman demokrasi (deepening democracy) yang mencakup (a) dimensi sosio-legal atau institusionalisasi hak-hak politik, yang merujuk pada gagasan hak asasi manusia, martabat manusia dan kesetaraan manusia; (b) dimensi ekonomi, yang merujuk pada distribusi dan alokasi sumber-sumber yang terdapat dalam masyarakat; dan (c) dimensi politik, yang merujuk pada partisipasi masyarakat dalam politik, khususnya dalam proses pembuatan kebijakan

\section{DAFTAR PUSTAKA}

Adnan, Z, .1990. Islamic Relegion: Yes, Islamic Ideology: No! Islam and the State Indonesia; dalam Arief Budiman (ed) State and civil Society In Indonesia; Clayton, Victoria: Centre of Southeast Asian Studies, Monash University

Alfian. 1980. Pemikiran dan Perubahan Politik Indonesia. Kumpulan Karangan; Jakarta: Penerbit PT Gramedia.

Anderson, Lisa (ed).1999. Transition to Democracy. Columbia University Press.

Bourchier, D \& J. Legge (eds). 1994. Democracy in Indonesia: 1950s and 1990s; Centre for Southeast Asian Studies, Monash University, Clayton, Victoria.

Budiardjo, M. 1980. Dasar-Dasar Ilmu Politik; Jakarta: Gramedia

Erb, M. \& Sulistyanto. P. 2009. Deepening Democracy in Indonesia? Direct Elections for Local Leaders (Pilkada); Singapore: ISEAS Publishing.

Goodwin.B. 1985. Using Political Ideas.New York:John Wiley \& Sons

Heuken SJ, Yulia Gunawan, H.E. Sinaga \& A. Hadi. 1988. Ensiklopedi Populer Politik Pembangun an Pancasila; Jakarta: Yayasan Cipta Loka Caraka.

Linz, Juan \& Stephan, Alfred.1996. Problems of Democratic Transition and Consolidation. John Hopkins University Press.

Macridis, R.C.1986. Contemporary Political Ideologies; Boston: Little, Brown and Company

Marijan, Kacung. 2010. Sistem Politik Indonesia. Konsolidasi Demokrasi Pasca-Orde Baru; Jakarta: Kencana Predana Media Group.

Noer, Deliar. 1983. Pengantar ke Pemikiran Politik; Rajawali, Jakarta. 
Pratikno, 2007. Mengelola Modal Politik untuk Pendalaman Demokrasi. ?; ?

Przeworski, Adam et al., "What Makes Democracies Endure?" Journal of Democracy, Vol 7. No. 1, 1996.

Suseno, F.M. 1995. Mencari Sosok Demokrasi. Sebuah Telaah Filosofis; Jakarta: PT Gramedia Pustaka Utama.

Wong, Joseph, "Deepening Democracy in Taiwan" Pacific Affairs , Vol 76, No. 2, Summer 2003. 